\title{
Determination of Iron in Alkaline Salts by ICP-AES Using 1-(2-Thiazolylazo)-p-Cresol (TAC) for Preconcentration and Separation
}

\author{
Sérgio L.C. Ferreira, Adriana S. Queiroz, Júlio C. R. Assis, \\ Maria das Graças A. Korn, and A. C. Spinola Costa
}

Instituto de Química, Universidade Federal da Bahia, 40170-290 Bahia, Brazil

Received: September 29, 1996; July 18, 1997

\begin{abstract}
O presente trabalho descreve o uso de 1-(2-thiazolylazo)-p-cresol (TAC) para separação, preconcentração e determinação de traços de ferro $\left(\mathrm{ng} \mathrm{g}^{-1}\right)$ em sais alcalinos usando a técnica ICP-AES. O método proposto é baseado na extração líquido-líquido do complexo formado entre o cátion ferro(III) e o 1-(2-thiazolylazo)-p-cresol (TAC). Foram estudados parâmetros tais como: quantidade de TAC, efeito de $\mathrm{pH}$, influência do solvente orgânico, mineralização da fase orgânica e re-extração. Os resultados demonstraram que o complexo ferro(III)-TAC, formado na faixa de $\mathrm{pH}$ de 4,0 a 10,0, pode ser quantitativamente extraído de soluções salinas, usando como solvente extractor álcool isoamílico, tetracloreto de carbono, clorofórmio ou metil isobutil cetona. A solução para determinação de ferro pode ser obtida por uma re-extração usando soluções de ácido clorídrico $1 \mathrm{~mol} / \mathrm{L}$ ou ácido nítrico $1 \mathrm{~mol} / \mathrm{L}$ ou também por uma mineralização da fase orgânica, com uma evaporação do solvente orgânico e digestão do resíduo com ácido nítrico concentrado. O procedimento foi usado para determinação de ferro em amostras de vários sais alcalinos. A técnica da adição padrão foi aplicada e as recuperações obtidas revelaram que o procedimento proposto tem uma boa exatidão.
\end{abstract}

The present paper describes the use of 1-(2-thiazolylazo)-p-cresol (TAC) for separation, preconcentration and determination of iron traces $\left(\mathrm{ng} \mathrm{g}^{-1}\right)$ in alkaline salts by the ICP-AES technique. The proposed method is based on the liquid-liquid extraction of the complex formed between iron(III) and 1-(2-thiazolylazo)-p-cresol (TAC). Parameters such as: TAC amount, pH effect, influence of the organic solvent on the extraction, back extraction and mineralization of the organic phase were studied. The results show that the iron(III)-TAC complex, formed in the $\mathrm{pH}$ range from 4.0 to 10.0 , can be quantitatively extracted from saline solutions (up to $30 \% \mathrm{NaCl}$ ) using isoamyl alcohol, carbon tetrachloride, chloroform or methyl isobutyl ketone as extracting solvent. The solution for the iron determination can be obtained by a back extraction using $1 \mathrm{~mol} / \mathrm{L}$ hydrochloric acid or $1 \mathrm{~mol} / \mathrm{L}$ nitric acid solutions or also by mineralization of the organic phase, which was accomplished by evaporation of the organic solvent and digestion of the residue with concentrated nitric acid. The procedure was used for iron determination in several alkaline salt samples. The standard addition technique was applied and the recoveries obtained revealed that the proposed procedure has a good accuracy.

Keywords: iron determination, ICP-AES, saline salts

\section{Introduction}

The determination of iron traces in alkaline salts by ICP-AES (inductively coupled plasma atomic emission spectrometry) is difficult because the aspiration of solu- tions with high salt concentrations into the plasma can cause problems such as: blockage of the nebulizer, considerable background emission, transport and chemical interferences, with consequent drop in sensitivity and precision $^{1-4}$. Thus, trace determination in saline solutions, 
always needs a prior separation. Several papers for determination of iron and other metal ions in saline matrices have been described in the literature ${ }^{5-10}$. Berman et al. ${ }^{5}$ proposed a procedure for the simultaneous determination of iron, manganese, copper, zinc and nickel in sea water by a combination of ion-exchange preconcentration and ICPAES. The sample is passed through a Chelex-100 column and trace metals are eluted by shaking the resin with 5 $\mathrm{mol} / \mathrm{L}$ nitric acid. Brooks et al. ${ }^{6}$ determined cobalt, copper, iron, lead, nickel and zinc in saline waters by simultaneous extraction of their ammonium pyrollidine dithiocarbamate (APDC) complexes into methyl isobutyl ketone (MIBK) and subsequent analysis by atomic absorption spectrometry. A procedure for the determination of iron, manganese, copper, zinc, cadmium, lead, vanadium and nickel in sea water was described by Sugimae ${ }^{7}$. In it, the trace elements are complexed with diethyldithiocarbamic acid (DDTC) and extracted with chloroform, followed by a decomposition of the extract and determination by using the ICP-AES technique. McLeod et al. ${ }^{8}$ proposed a method for preconcentration and determination of iron, copper, nickel, cadmium, vanadium and zinc from sea water by ICP-AES. It was based on liquid-liquid extraction with dithiocarbamate, using chloroform as the extraction solvent and back extraction with nitric acid. Nakashima et $a l .{ }^{9}$ reported the use of graphite furnace atomic absorption spectrometry in combination with the silica immobilized 8-hydroxyquinoline miniature column flow system for the preconcentration of iron and other metal ions from sea water. Watanabe ${ }^{10}$ described a preconcentration method for iron and other metal ions from sea water prior to the determination by ICP-AES. The method involved complexation of the metal ions with 8-hydroxyquinoline followed by adsorption on a column of $\mathrm{C}_{18}$-bonded silica gel.

In this paper, a procedure for separation, preconcentration and determination of iron in alkaline salts by ICP-AES, based on the liquid-liquid extraction of the iron(III)-TAC (1-(2-thiazolylazo)-p-cresol ) complex, followed by a back extraction or a mineralization process of the organic phase is proposed. The TAC reacts instantaneously with iron(III) forming a stable complex. This reagent was used for iron determination by molecular absorption spectroscopy ${ }^{11,12}$ and also by cathodic adsorptive stripping voltammetry ${ }^{13}$. TAC has been proposed several times as a spectrophotometric reagent. Methods for determination of zirconium ${ }^{14}$, bismuth $^{15}$, yttrium $^{16}$ were described. In our laboratory, it was employed for the spectrophotometric determination of titanium ${ }^{12}$, nickel $^{17}$, indium ${ }^{18}$ and lead ${ }^{19}$ using several masking agents to increase the selectivity.

\section{Experimental}

\section{Apparatus}

An Applied Research Laboratories model 3410 minitorch sequential inductively coupled plasma spectrometer with an IBM PC-AT computer was used. The emission intensity measurements were made under the conditions shown in Table 1. A 300 ANALYSER pH meter was also used.

\section{Reagents}

All reagents were of analytical reagent grade unless otherwise stated. Double distilled water was used for the preparation of the solutions. The nitric acid and hydrochloric acid were Suprapur from Merck. The laboratory glassware was kept overnight in a 5\% nitric acid solution. Before use, the glassware was washed with deionized water and dried in a dust-free environment.

Iron(III) solution $(10.00 \mu \mathrm{g} / \mathrm{mL})$. Prepared by dilution of a $1000 \mu \mathrm{g} / \mathrm{mL}$ iron solution (for atomic absorption, Aldrich) using a 5\% hydrochloric acid solution. TAC solution $(1.00 \%)$. Prepared by dissolving $1.00 \mathrm{~g}$ (Aldrich) in $100 \mathrm{~mL}$ of ethanol. Buffer solution ( $\mathrm{pH} 4.75)$. Prepared by mixing $68.0 \mathrm{~g}$ of sodium acetate trihydrate and $29.4 \mathrm{~mL}$ of glacial acetic acid in 11 of demineralized water.

\section{General Procedure}

In a $250 \mathrm{~mL}$ separation funnel, transfer $100 \mathrm{~mL}$ of a solution containing iron(III) in the range of 2.0 to $100.0 \mu \mathrm{g}$, $2.5 \mathrm{~mL}$ of acetate buffer $(\mathrm{pH} 4.75)$ and $1.0 \mathrm{~mL}$ of $1 \%$ TAC solution. Mix and after 5 min make the extraction using 30 $\mathrm{mL}$ of the organic solvent.

Table 1. Operating parameters for the inductively coupled plasma spectrometer.

\begin{tabular}{lc}
\hline Incident output power & $650 \mathrm{~W}$ \\
Reflected power & $<5 \mathrm{~W}$ \\
Nebulizer & Glass, Meinhard \\
Plasma gas flow rate & $7.5 \mathrm{~L} \mathrm{~min}^{-1}$ \\
Auxiliary gas flow rate & $0.8 \mathrm{~L} \mathrm{~min}^{-1}$ \\
Aerosol carrier gas flow rate & $0.8 \mathrm{~L} \mathrm{~min}^{-1}$ \\
Solution uptake rate & $2.5 \mathrm{~mL} \mathrm{~min}^{-1}$ \\
Wavelength & $259.93 \mathrm{~nm}^{-1}$ \\
Signal integration time & $5 \mathrm{~s}^{-}$ \\
Integration for determination & 3 \\
\hline
\end{tabular}




\section{Results and Discussion}

\section{Characteristics of TAC and iron(III)-TAC complex}

The TAC reacts instantaneously with the iron(III) cation, forming a stable complex with a composition of $1: 2$ cation-reagent. TAC and its iron complex have low solubility in water, but are very soluble in organic solvents, allowing the extraction of TAC and its complex. The TAC is not selective for the iron determination, However, $\mathrm{pH}$ control increases the selectivity.

\section{TAC amount}

In order to test the reagent amount for quantitative extraction of iron, different amounts of TAC from $500 \mu \mathrm{g}$ to $20 \mathrm{mg}$ were added to a series of $100 \mathrm{~mL}$ solutions containing $20.0 \mu \mathrm{g}$ of iron and the general procedure was applied, using $30 \mathrm{~mL}$ of isoamyl alcohol. The results showed that the extraction was quantitative, for a TAC amount greater than $800 \mu \mathrm{g}$. In the proposed procedure, a TAC amount of $10 \mathrm{mg}$ is recommended to guarantee the complete complexation of the iron present in the samples, considering that it can also react with other metal cations.

\section{pH effect on the extraction}

The $\mathrm{pH}$ effect on the extraction of the iron(III)-TAC complex was studied and the results showed that it is maximum and quantitative in a $\mathrm{pH}$ range from 4.0 to 10.0. The extraction is not quantitative at $\mathrm{pH}$ lower than 4.0, due to competition between the hydrogen ion and the iron(III) cation. With the increase of the hydrogen ion concentration, the competition leads to a less favorable complex formation and consequent extraction of TAC. The $\mathrm{pH}$ control was done using acetate buffer with $\mathrm{pH} 4.0$ and 6.0, borate buffer with $\mathrm{pH} 8.0$ and ammonium buffer with $\mathrm{pH} 10.0$. For $\mathrm{pH}$ 2.0 and 12.0, solutions of hydrochloric acid and sodium hydroxide were used respectively. In the proposed procedure an acetate buffer with $\mathrm{pH} 4.75$ is recommended because at this $\mathrm{pH}$, the TAC reagent is more selective and the buffer index of the acetate buffer is maximum.

\section{Effect of electrolytes on the extraction of the iron(III)-TAC complex}

The influence of electrolytes on the extraction of the iron(III)-TAC complex was studied and the results showed that it is quantitative even in the presence of $100 \mathrm{~mL}$ of $30 \%$, w/v, sodium chloride solution or of $100 \mathrm{~mL}$ of $30 \%$, $\mathrm{w} / \mathrm{v}$, potassium nitrate. The salting out effect allowed a more rapid extraction.

\section{Effect of the organic solvent}

In order to investigate the influence of the organic solvent on the extraction of the iron(III)-TAC complex, several organic solvents with different properties were tested. The results demonstrated that the solvents isoamyl alcohol, carbon tetrachloride, chloroform and methyl isobutyl ketone allow quantitative extraction.

\section{Back extraction of iron to aqueous medium}

The introduction of the organic solvents used in this work into the plasma (low-power) presents considerable operational difficulties due to the loading of the plasma with large quantities of organic vapor, destabilizing the plasma, often to the point of extinction. Thus, solutions of $1 \mathrm{~mol} / \mathrm{L}$ nitric acid and $1.0 \mathrm{~mol} / \mathrm{L}$ hydrochloric acid were tested for the back extraction of the complexed iron. The results showed that for both solutions the back extraction is quantitative. The recoveries (mean of 3 determinations) were $99.90 \%$ using nitric acid solution and $92.50 \%$ for hydrochloric acid solution. These results were obtained using isoamyl alcohol as solvent for the extraction of the complex.

\section{Mineralization of the organic solvent}

Another way to obtain an appropriate solution for iron determination by ICP-AES is to evaporate the organic solvent containing TAC and its iron complex, followed by digestion by heating the residue with $5.0 \mathrm{~mL}$ of concentrated nitric acid and dilution with $2 \%, \mathrm{v} / \mathrm{v}$, hydrochloric acid solution. The obtained recovery (mean of 3 determinations) was $99.9 \%$.

\section{Analytical characteristics}

The proposed procedure can be applied to preconcentration and separation of iron, in the range of 1.0 to 100.0 $\mu \mathrm{g}$, contained in a solution volume of 50 to $500 \mathrm{~mL}$, by using $30 \mathrm{~mL}$ of organic solvent, making a single extraction.

The calibration graph $(0-2.0 \mu \mathrm{g} / \mathrm{L})$ of iron was obtained with solutions prepared from $1 \mathrm{mg} / \mathrm{L}$ stock solution. The correlation coefficient was 0.9998 .

The detection limit for the proposed procedure was $7.6 \mu \mathrm{g} / \mathrm{L}$. The precision of the method, evaluated as the relative standard deviation obtained after analyzing a series of seven replicates, was $3.2 \%$ to $10.0 \mu \mathrm{g}$ of iron contained in a solution volume of $250 \mathrm{~mL}$.

\section{Application}

For the mineralization process of the organic solvent phase, carbon tetrachloride and chloroform are better because these have lower boiling points and higher vapor pressures than isoamyl alcohol, thus are evaporated more easily. However, for back extraction the isoamyl alcohol is better due to its lower density compared with water.

The proposed method was applied to iron determination in previously dried alkaline salts. The standard addition technique was applied and the obtained recoveries revealed 
Table 2. Determination and recovery of iron in alkaline salt samples.

\begin{tabular}{|c|c|c|c|c|}
\hline Sample & $\begin{array}{l}\text { Concentration of the salt } \\
(\%)\end{array}$ & $\begin{array}{l}\text { Concentration added } \\
\text { (ng/g salt) }\end{array}$ & Iron found (ng/g salt)* & Recovery (\%) \\
\hline \multirow[t]{2}{*}{$\mathrm{NaCl}$ Reagen } & 30 & 0 & $502 \pm 17$ & --- \\
\hline & & 667 & $1194 \pm 21$ & 104 \\
\hline \multirow[t]{2}{*}{$\mathrm{NaCl}$ Carlo Erba } & 30 & 0 & $237 \pm 12$ & --- \\
\hline & & 667 & $893 \pm 17$ & 98 \\
\hline \multirow[t]{2}{*}{$\mathrm{KNO}_{3}$ Vetec } & 25 & 0 & $444 \pm 12$ & --- \\
\hline & & 400 & $864 \pm 17$ & 105 \\
\hline \multirow[t]{2}{*}{$\mathrm{KCl}$ Carlo Erba } & 25 & 0 & $148 \pm 9$ & --- \\
\hline & & 400 & $513 \pm 15$ & 91 \\
\hline
\end{tabular}

$*$ at $95 \%$ confidence level.

that the proposed procedure has a good accuracy. The results are shown in Table 2.

\section{Conclusions}

The proposed method is very important and fortunate, for the analytical problem of the determination of metal traces in alkaline salts by ICP-AES, and the fact that iron is frequently present at trace levels in these samples. The procedure for preconcentration and separation is simple, and can be also applied to the determination of iron using other analytical techniques for which the trace separation from saline matrices is nearly always inevitable.

The obtained recovery, measured through the standard addition technique, revealed that the proposed procedure has good accuracy.

\section{Acknowledgments}

The authors acknowledge financial support from CNPq, FINEP and CAPES.

\section{References}

1. Boumans, W.J.M. In Inductively Coupled Plasma Emission Spectroscopy. Part 1: Methodology, Instrumentation and Performance, Intercience, New York, 1987.

2.Bekjarov, G.; Kmetov, V. Fresenius Z. Anal.Chem. 1989, 335, 971.

3. Budic, B.; Hudnik, V. J. Anal. At. Spectrom. 1994, 9 , 53.
4. Montaser, A.; Golightly, D.W. In Inductively Coupled Plasma in Analytical Atomic Spectrometry, VHC Publishers, New York, 1990.

5.Berman, S.S.; McLaren, J.W.; Willie, S.N. Anal Chem. 1980, 52, 488.

6. Brooks, R.R.; Presley, B.J.;. Kaplan, I.R. Talanta 1967, 14, 809.

7. Sugimae, A. Anal. Chim. Acta 1980, 121, 331.

8. McLeod, C.W.; Otsuki, A.; Okamoto, K.; Haraguchi, H.; Fuwa, K. Analyst 1981, 106, 419.

9. Nakashima, S.; Sturgeon, R.E.; Willie, S.N.; Berman, S.S. Frezenius Z. Anal. Chem. 1988, 330, 592.

10. Watanabe, H.; Goto, K.; Taguchi, S.; McLaren, J.W. Berman, S.S.; Russel, D.S. Anal. Chem. 1981, 53, 738.

11. Ueda, K. Nippon Kagaku Kaishi 1981, 7, 111.

12. Ferreira, S.L.C.; Costa, A.C.S.; Andrade, H.A.S. Mikrochimica Acta 1993, 111, 119.

13. Fárias, P.A.M.; Ohara, A.K.; Ferreira, S.L.C. Anal. Lett. 1992, 25, 1929.

14.Gusev, S.I.; Gavrilova, N.F.; Kurepa, G.A.; Poplevina, L.V. Zh. Anal. Khim. 1974, 29, 1955.

15. Tsurumi, K.; Furuya, H.; Kamata, H. Nippon Kagaku Kaishi 1977, 10, 1469.

16. Tsurumi, K.; Furuya, H.; Kamata, H. Anal. Lett. 1980, $13 A(4), 319$.

17. Ferreira, S.L.C. Talanta 1988, 35, 485.

18. Ferreira, S.L.C.; Costa, A.C.S.; Andrade, H.A.S. Mikrochimica Journal 1991, 44, 63.

19. Ferreira, S.L.C.; Andrade, M.G.M.; Lopo, I.P.; Costa, A.C.S. Anal. Lett. 1991, 24, 1675. 